\title{
ГІСТОЛОГІЧНІ ЗМІНИ НАДНИРКОВИХ ЗАЛОЗ У ПІЗНІ ТЕРМІНИ ПІСЛЯ ЕКСПЕРИМЕНТАЛЬНОЇ ТЕРМІЧНОЇ ТРАВМИ ТА ЗАСТОСУВАННЯ ПОДРІБНЕНОГО СУБСТРАТУ ЛІОФІЛІЗОВАНОЇ КСЕНОШКІРИ
}

Гістологічні зміни надниркових залоз у пізні терміни після експериментальної термічної травми та застосування подрібненого субстрату ліофілізованої ксеношкіри

\section{В. В. Кульбіцька, 3. М. Небесна, О. Я. Шутурма}

Тернопільський національний медичний університет імені І. Я. Горбачевського МОЗ України

Резюме. Термічні травми за поширеністю, ускладненнями та летальністю займають лідируючі позиціі серед інших захворювань у світі. Проте морфоорункціональні зміни в надниркових залозах у пізні терміни після опікової травми не достатньо вивчені. На сьогодні важливим завданням $є$ пошук ефективних чинників лікування опікових уражень. Одним із сучасних методів $\epsilon$ використання ліофілізованої ксеношкіри.

Мета дослідження - встановити структурну реорганізацію компонентів надниркових залоз у пізні терміни після термічної травми та за умов застосування субстрату ліофрілізованої ксеношкіри.

Матеріали і методи. Експериментальна термічна травма змодельована на 20 лабораторних білих щурах-самцях. Опік III ступеня наносили під тіопенталнатрієвим наркозом мідними пластинами, нагрітими у кип'яченій воді до температури 97-100 C. Розміри ділянки ураження склали 18-20 \% поверхні тіла тварин. Мікроскопічне дослідження структурних компонентів надниркових залоз вивчали за допомогою світлового мікроскопа MICROmed SEO SCAN.

Результати. Згідно з проведеними гістологічними дослідженнями надниркових залоз після експериментальної термічної травми за умов застосування субстрату ксеношкіри на 14 добу експерименту виявлено, що в кірковій речовині кількість некротично і деструктивно змінених клітин менша, порівняно із попередніми мікроскопічними дослідженнями надниркових залоз після опіку, які ми провели. Спостерігаються в невеликій кількості деструктивно змінені клітини 3 ознаками інтра- і перицелюлярного набряку. В мозковій речовині органа встановлені ознаки незначної деструкції хромафріноцитів, для гемокапілярів характерні розширені просвіти та помірне кровонаповнення. Результати гістологічного дослідження надниркових залоз на 21 добу показали, що структурна організація зон кори органа наближена до норми. Набряк стромального компоненту та паренхіми незначний. Виявлялись
Histological changes of the adrenal gland in the late period after experimental thermal injury and application of lyophilized xenograft skin substrate

V. V. Kulbitska, Z. M. Nebesna, O. Ya. Shuturma I. Horbachevsky Ternopil National Medical University

e-mail: kulbitska@tdmu.edu.ua

Summary. Thermal injury in terms of prevalence, complications and mortality occupy a leading position among other diseases in the world. However, morphofunctional changes of the adrenal gland in the late period after thermal injury have not been sufficiently studied. Today, an important task is to find effective factors in the treatment of burns. One of the modern methods is the use of lyophilized xenograft skin substrate.

The aim of the study - to establish the structural reorganization of the adrenal gland components in the late period after thermal injury and under the conditions of application of the lyophilized xenograft skin substrate.

Materials and Methods. The experimental thermal injury was carried out on 20 white adult male laboratory rats. Third degree burns were applied under thiopental-sodium anesthesia with copper plates heated in boiling water to a temperature of $97-100^{\circ} \mathrm{C}$. The size of the lesions was 18$20 \%$ of the animals' body surface. Microscopic examination of the adrenal gland structural components was perfomed by light microscope MICROmed SEO CCAN.

Results. According to histological examinations of the adrenal gland after experimental thermal trauma under conditions of application of the lyophilized xenograft skin substrate on the 14th day of the experiment, it was found that the number of necrotic cells in the cortex is less compared to our previous microscopic examinations of the adrenal gland after burns. Destructively altered cells with signs of intra- and pericellular edema are observed singly. There are signs of slight destruction of chromafinocytes in the medulla of the organ; hemocapillaries characterized by dilated lumens and moderate blood supply. Histological examination of the adrenal gland on the 21st day of experiment showed that the structural organization of the cortex is close to normal condition. Swelling of the stromal component and parenchyma is insignificant. Single endocrinocytes with signs of damage were detected. Endocrinocytes of the adrenal gland medulla are slightly 
поодинокі ендокриноцити з ознаками ушкодження. Ендокриноцити мозкової речовини залоз малозмінені. Крововиливів та периваскулярного набряку не спостерігалось, також не виявлялися явища стазу та дистрофрічні порушення.

Висновки. У пізні терміни експерименту за умов корекції відбувається відносна нормалізація структурної організації надниркових залоз, що свідчить про активізацію обмінних процесів в організмі.

Ключові слова: надниркові залози; гістологічні зміни; термічна травма; ліофрілізована ксеношкіра.

\section{ВСТУП}

У наш час проблема термічної травми за поширеністю, ускладненнями та летальністю займає лідируючі позиції в світі серед інших видів травматичних уражень [1-3]. Термічний опік шкіри $€$ головним чинником розвитку опікової хвороби, в патогенезі якої значну роль відіграють надниркові залози, виділяючи гормони, що призводять до мобілізації захисних фрункцій та ровитку пристосувально-компенсаторних реакцій організму [4-6]. Водночас, морфоофункціональні зміни залоз у пізні терміни після термічної травми, коли унаслідок різкого порушення метаболізму виникає поліорганна недостатність, недостатньо вивчені [7]. На сьогодні важливим завданням $€$ пошук ефективних чинників лікування опікових уражень $[8,9]$. Зокрема, для закриття опікової рани використовують подрібнений субстрат ліофрілізованої ксеношкіри, який завдяки високим адсорбційним властивостям поглинає значну кількість токсинів, сприяє видаленню їх з рани та проникненню в кровообіг, тим самим забезпечуючи ефективну регенерацію не тільки ранової поверхні, але й відновлення морфофрункціонального стану всіх органів організму, зокрема надниркових залоз [10-12].

Метою дослідження було встановити гістологічні зміни надниркових залоз у пізні терміни після експериментальної термічної травми та за умов застосування подрібненого субстрату ліофілізованої ксеношкіри.

\section{МАТЕРІАЛИ I МЕТОДИ}

Експериментальне дослідження проведено на 20 статевозрілих щурах-самцях. Тварин утримували у віварії Тернопільського національного медичного університету імені І. Я. Горбачевського МОЗ України. Утримання та маніпуляції з тваринами проведено відповідно рекомендацій Європейської конвенції про захист хребетних тварин, що використовуються для дослідних та інших наукових цілей (Страсбург, 1986) та відповідно до Загальних етичних принципів експериментів на тваринах, ухваленим Першим національним конгресом з біоетики (Київ, 2001). Опік III altered. Hemorrhage and perivascular edema were not observed. The phenomena of stasis and dystrophic disorders were not detected.

Conclusions. In the late period of the experiment under conditions of correction there is relative normalization of the adrenal gland structural organization, which indicates the activation of metabolic processes in the body.

Key words: adrenal gland; histological changes; thermal trauma; lyophilized xenograft skin.

ступеня моделювали під тіопентал-натрієвим наркозом мідними пластинами, нагрітими у воді до температури 97-100 ${ }^{\circ} \mathrm{C}$ на епільовану поверхню шкіри спини тварин протягом 15 с. Загальна площа опіку склала 18-20 \% поверхні тіла щурів. Тварин декапітували на 14 та 21 доби після моделювання термічної травми, що відповідає стадії пізньої токсемії та септитоксемії опікової хвороби. Після декапітації дослідних тварин здійснювали забір надниркових залоз для гістологічного дослідження [13, 14].

Шматочки надниркових залоз фріксували в $96^{\circ}$ спирті та в $10 \%$ нейтральному розчині фрормаліну, заливали в парафрінові блоки. Виготовлені на санному мікротомі гістологічні зрізи товщиною 5-6 мкм забарвлювали гематоксиліном та еозином. Мікропрепарати вивчали за допомогою світлового мікроскопа MICROmed SEO SCAN та фротодокументували за допомогою відеокамери Vision CCD Camera з системою виводу зображення з гістологічних препаратів.

\section{РЕЗУЛЬТАТИ Й ОБГОВОРЕННЯ}

Згідно з проведеними гістологічними дослідженнями надниркових залоз дослідних тварин у пізні терміни після експериментальної термічної травми та за умов застосування подрібненого субстрату ліофілізованої ксеношкіри на 14 добу експерименту виявлено, що капсула помірної товщини, під якою чітко розрізнялась кіркова і мозкова речовини органа (рис. 1).

У клубочковій зоні надниркових залоз кортикоцити великих розмірів розташовувались компактно, мали слабо оксифрільну цитоплазму та великі гіперхромні ядра, контури плазмолем добре виражені. Проте визначалась незначна кількість клітин із зонами просвітленої цитоплазми та ознаками набряку. Ядра клітин великі, округлі, нормохромні. Кількість некротично змінених клітин з пікнотизованими ядрами невелика.

У даний термін експерименту пучкова зона була розширена, в ній виявлялись клітини збільшеної площі з прозорою пінистою цитоплазмою та чисельними дрібними вакуолями. Проте більшість кортикоцитів цієї зони характеризувались темною цитоплазмою. Змінені клітини 3 явищами дистрофії
Вісник медичних і біологічних досліджень Bulletin of Medical and Biological Research
$2(8), 2021$ 


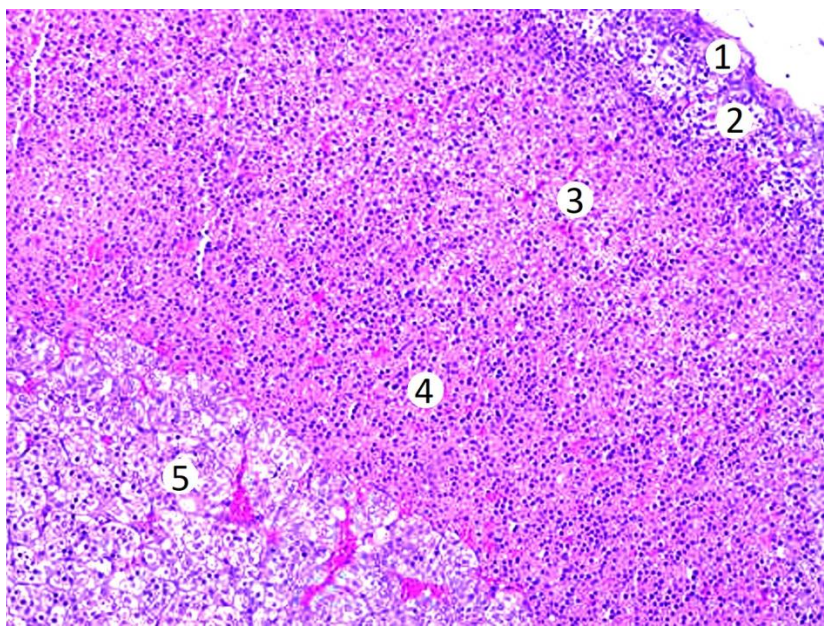

Рис. 1. Гістологічні зміни надниркової залози на 14 добу після експериментальної термічної травми та за умов корекції субстратом ліофілізованої ксеношкіри: 1 - сполучнотканинна капсула, 2 - клубочкова зона, 3 - пучкова зона, 4 - сітчаста зона, 5 - мозкова речовина. Забарвлення гематоксиліном та еозином. х100.

поодинокі. Ядра більшості клітин нормохромні, 3 чіткими ядерцями (рис. 2). Сітчаста зона кори залоз містила великі полігональні кортикоцити з слабо оксифрільною світлою вакуолізованою цитоплазмою та округлими базофільними ядрами.

На 14 добу експерименту в мозковій речовині органа встановлені ознаки відновлення структури як хромасріноцитів, так і елементів мікроциркуляторного русла. Клітини з явищами набряку цитоплазми практично відсутні, проте зустрічались поодинокі дистрофічно змінені клітини (рис. 3). Переважно спостерігались округлі великі клітини 3 світлою цитоплазмою та чисельними дрібними вакуолями, з добре помітними ядерцями в ядрах. У мозковій речовині органа спостерігались гемокапіляри 3 широкими просвітами, з ендотеліальними клітинами, що були фррагментарно ушкоджені. Озна-

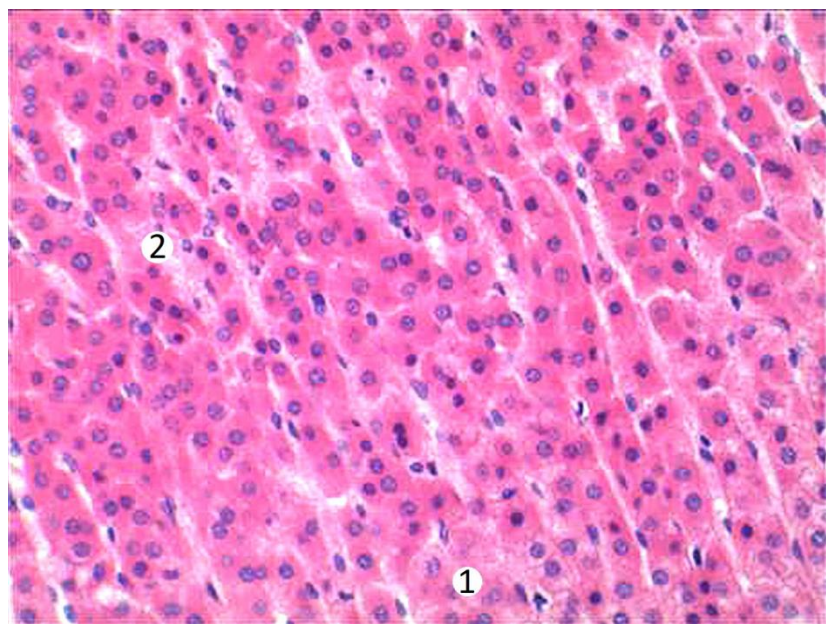

Рис. 2. Мікроскопічні зміни пучкової зони кори надниркової залози на 14 добу експерименту після корекції субстратом ксеношкіри: 1 - деструктивно змінені клітини, 2 - кровонаповнені гемокапіляри. Забарвлення гематоксиліном та еозином. х400. ки набряку інтерстицію слабовиражені, відсутні явища діапедезу еритроцитів.

На 14 добу дослідження в прошарках сполучної тканини відмічались гемокапіляри 3 неширокими просвітами та нерівномірним кровонаповненням. Ендотеліальне вистелення судин суцільне, без ознак відшарування та ушкодження. Деякі капіляри виглядали оптично порожніми. Деякі судини були розширені та кровонаповнені з незначною перивазальною інфільтрацією лейкоцитами, особливо у сітчастій зоні. Сполучна тканина навколо судин була з ознаками помірного набряку.

Результати гістологічних досліджень надниркових залоз на 21 добу експерименту показали, що структурна організація зон кори органа наближається до норми. Однак у клубочковій зоні виявлялись поодинокі ендокриноцити 3 ознаками деструкції, вони мали нерівні контури плазмолеми та набряку цитоплазми, гіперхромні темні ядра 3 нерівними контурами каріолеми.

Незначна вакуолізація спостерігалась в деяких клітинах пучкової зони, яка була помірно потовщена. Набряк стромального компонента та паренхіми практично відсутній. Клітини переважно видовженої призматичної форми, розташовувались у вигляді поздовжніх тяжів. Цитоплазма більшості кортикоцитів світла з чисельними дрібними вакуолями. Ядра містили переважно еухроматин та великі базофільно забарвлені ядерця (рис. 4). У сітчастій зоні переважали компактні клітини з чіткими контурами. Мікросудини цієї зони були помірно кровонаповнені з цілою стінкою та відсутня інфрільтрація лейкоцитами.

Результати мікроскопічних досліджень мозкової речовини надниркових залоз на 21 добу після експериментальної термічної травми та застосуванні коригувального чинника показали, що більшість ендокриноцитів була малозмінена (рис. 5). Цито-

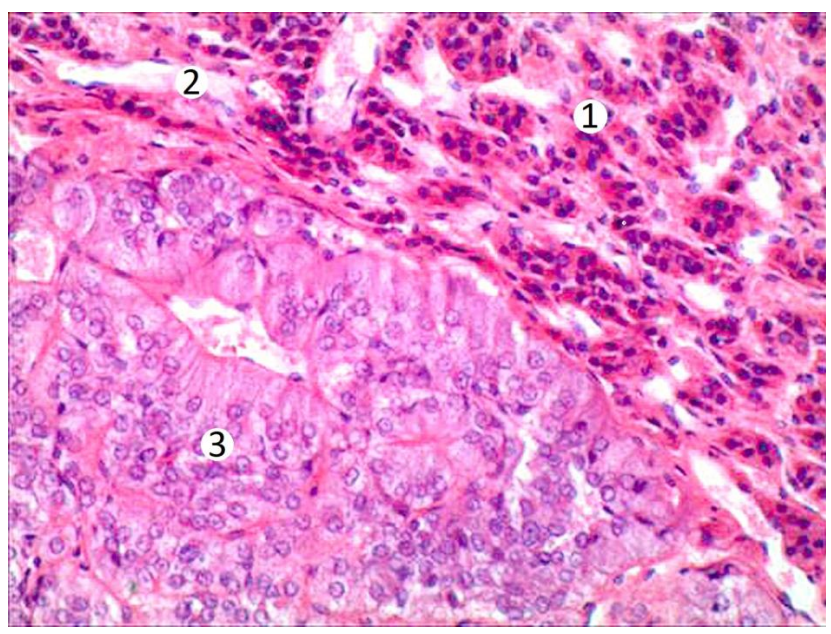

Рис. 3. Гістологічний стан мозкової речовини надниркової залози на 14 добу після експериментальної термічної травми та корекції субстратом ксеношкіри: 1 - ендокриноцити сітчастої зони, 2 - гемокапіляри, 3 - ендокриноцити мозкової речовини. Забарвлення гематоксиліном та еозином. х200. 


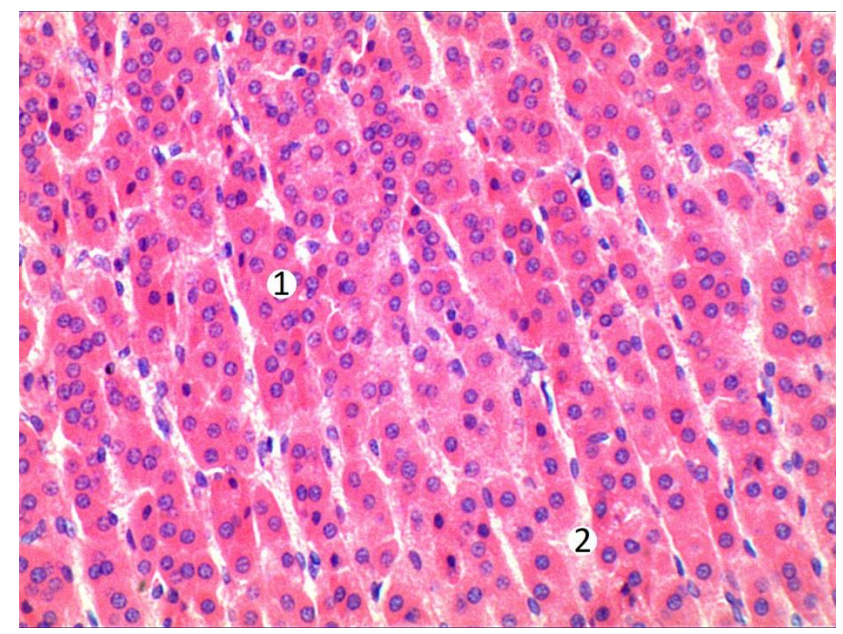

Рис. 4. Мікроскопічна будова пучкової зони кори надниркової залози на 21 добу після термічної травми та корекції подрібненим субстратом ліофілізованої ксеношкіри: 1 - ендокриноцити, 2 - капіляри. Забарвлення гематоксиліном та еозином. х200.

плазма більшості епінефроцитів світла, з дрібними вакуолями та добре помітними темними ядерцями. Норепінефроцити характеризувались темнішою цитоплазмою, в якій також містились вакуолі. В мозковій речовині крововиливів та периваскулярного набряку не спостерігалось, не було виявлено дистрофрічних порушень стінки судин, явища стазу були поодинокі. Деякі капіляри були повнокровні, в них виявлялися еритроцити. Ендотелій судин без ушкоджень та відшарування.

Мікроскопічно встановлено, що за умов застосування коригувального чинника на 21 добу після експерименту структура судин органа покращується порівняно з попереднім терміном дослідження. Надмірно кровонаповнені судини практично відсутні, периваскулярний набряк стінки судин та сполучної тканини органа незначний. Стінки судин збережені та добре структуровані. Стінка гемокапілярів не потовщена, без ознак набряку інтерстицію.

Результати експерименту є основою для подальших моророметричних та субмікроскопічних досліджень структурних компонентів кіркової та мозкової речовин залоз та їх мікроциркуляторного русла при термічній травмі та за умов корекції.

\section{СПИСОК ЛІТЕРАТУРИ}

1. Нетюхайло Л. Г. Патогенез опікової хвороби (в 2 частинах) / Л. Г. Нетюхайло, С. В. Харченко, А. Г. Костенко // Світ медицини та біології. - 2011. - № 1. - С. 127-35.

2. Burns: Pathophysiology of systemic complications and current management / C. B. Nielson, N. C. Duethman, J. M. Howard [et al.] // J. Burn Care Res. - 2017. - Vol. 38 (1). - P. 469-81. DOI: 10.1097/BCR.0000000000000355

3. Burn injury / M. G. Jeschke, M. E. van Baar, M. A. Choudhry [et al.] // Nat. Rev. Dis. Primers. - 2020. Vol. 6 (1). - P. 11. DOI: 10.1038/s41572-020-0145-5

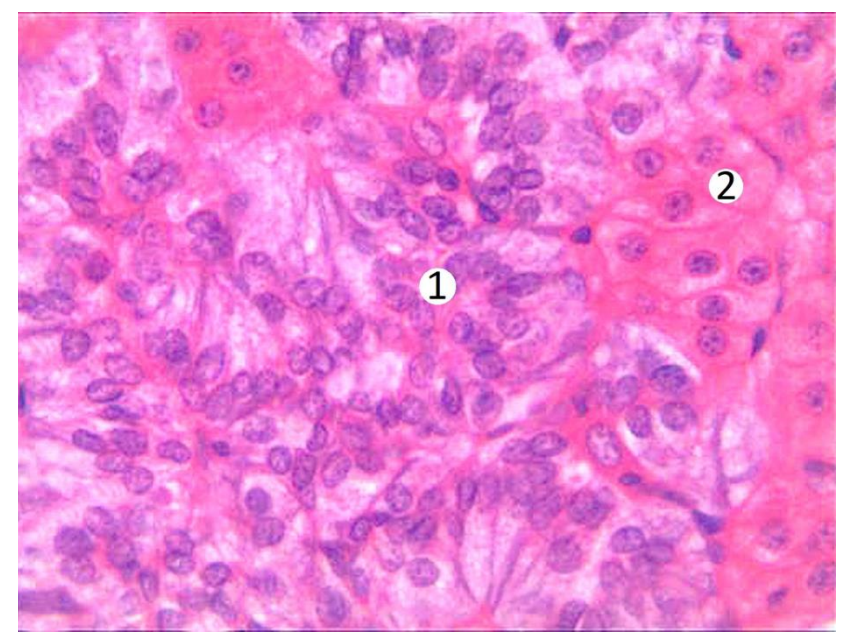

Рис. 5. Мікроскопічна будова мозкової речовини надниркової залози на 21 добу після експериментальної термічної травми та корекції подрібненим субстратом ліофілізованої ксеношкіри: 1 - хромафріноцити мозкової речовини, 2 - кортикоцити сітчастої зони кіркової речовини. Забарвлення гематоксиліном та еозином. х400.

\section{ВИСНОВКИ}

1. Результати мікроскопічних досліджень свідчать про те, що проведення ранньої некректомії уражених тканин після змодельованої термічної травми та подальше закриття рани подрібненим субстратом ліофрілізованої ксеношкіри створюють умови для активного перебігу регенераторних процесів в органі та запобігають дії патогенного фрактора на організм.

2. У пізні терміни експерименту (14 та 21 доби) за умов застосування коригувального фрактора відбувається відносна нормалізація структурної організації надниркових залоз, число деструктивно змінених клітин зменшується, інтра- та периваскулярний набряк практично відсутній, товщина капсули органа та архітектоніка зон кори наближається до норми.

3. Після проведеної експериментальної термічної травми та подальшої її корекції субстратом ксеношкіри відновлюється структура судин мікроциркуляторного русла надниркових залоз, що свідчить про активізацію обмінних процесів в організмі. Кровонаповнення, стаз та ендотеліальне відшарування судин виявляються рідко.

4. Структурні зміни органів нейроімуноендокринної системи при експериментальній опіковій хворобі та ії̈ інфузійної терапії / І. В. Гунас, О. І. Ковальчук, Е.В.Черкасов [та ін.] // Науковий вісник НМУ імені О.О. Богомольця. - 2013. - № 4(43). - C. 27-35.

5. The metabolic stress response to burn trauma: current understanding and therapies / C. Porter, R. G. Tompkins, C. C. Finnerty [et al.] // Lancet. - 2016. - Vol. 388 (10052). - P. 1417-1426.

6. Ryan C. M. Functional outcomes following burn injury /
$2(8), 2021$ 
C. M. Ryan, I. Parry, R. Richard // Journal of Burn Care \& Research. - 2017. - Vol. 38 (3). - P. e614-e617. DOI: 10.1097/bcr.0000000000000537

7. Multiple organ failure as a cause of death in patients with severe burns / O. Kallinen, K. Maisniemi, T. Bohling [et al.] // J. Burn. Care Res. - 2012. - Vol. 33 (2). - P. 206-211. DOI: 10.1097/BCR.0b013e3182331e73

8. Acute and perioperative care of the burn-injured patient / E. A. Bittner, E. Shank, L. Woodson, J. A. Martyn // Anesthesiology. - 2015. - Vol. 122. - P. 448-464. DOI: 10.1097/ALN.0000000000000559.

9. Young A. W. Rehabilitation of burn injuries / A. W. Young, W. S. Dewey, B. T. King // Physical Medicine and Rehabilitation Clinics of North America. - 2018. - Vol. 30 (1). - P. 111-132. DOI: 10.1016/j.pmr.2018.08.004

10. П'ятницький О. Ю. Експериментальне дослідження фрармакологічних властивостей субстрату кріоконсервованої шкіри свині / О. Ю. П'ятницький, Л. В. Яковлєва,

\section{REFERENCES}

1. Netyukhaylo LG, Kharchenko SV, Kostenko AG. [Pathogenesis of burn disease (in 2 parts)]. Svit medytsyny ta biolohii. 2011;1: 127-35. Ukrainian.

2. Nielson CB, Duethman NC, Howard JM, Moncure M, Wood JG. Burns: Pathophysiology of systemic complications and current management. J Burn Care Res. 2017;38(1): 46981. DOI: $10.1097 / B C R .0000000000000355$

3. Jeschke MG, van Baar ME, Choudhry MA, Chung KK, Gibran NS, Logsetty S. Burn injury. Nature Reviews Disease Primers. 2020;6(1). DOI:10.1038/s41572-020-0145-5

4. Gunas IV, Kovalchuk OI, Cherkasov EV, Dzevulska IV, Tytarenko VM. [Structural changes of the neuroimmunoendocrine system organs in experimental burn disease and its infusion]. Naukovyi visnyk NMU imeni O.O. Bohomoltsia. 2013;4(43): 27-35. Ukrainian.

5. Porter C, Tompkins RG, Finnerty CC, Sidossis LS, Suman OE, Herndon DN. The metabolic stress response to burn trauma: current understanding and therapies. Lancet. 2016;388(10052): 1417-26.

6. Ryan CM, Parry I, Richard R. Functional outcomes following burn injury. Journal of Burn Care \& Research. 2017;38(3), e614-e617. DOI:10.1097/bcr.0000000000000537

7. Kallinen $\mathrm{O}$, Maisniemi K, Bohling T, Tukiainen E, Koljonen V. Multiple organ failure as a cause of death in patients with severe burns. J Burn Care Res. 2012;33(2): 206-11. DOI: 10.1097/BCR.0b013e3182331e73

8. Bittner EA, Shank E, Woodson L, Martyn JA. Acute and
О. Ю. Кошова // Клін. фрармація. - 2013. - № 17(1). C. $56-62$.

11. Цимбалюк А. В. Використання подрібненого субстрату ліофілізованого ксенодермоімплантата для місцевого лікування опікових хворих з інфікованими ранами III-IV ступенів / А. В. Цимбалюк, Н. В. Гуда, О.О.Кирик // Шпитальна хірургія. - 2013. - № 1. - С. 81-84.

12. Skin xenotransplantation: Historical review and clinical potential / T. Yamamoto, H. Iwase, T. W. King [et al.] // Burns. - 2018. - Vol. 44. - P. 1738-1749. DOI: 10.1016/j. burns.2018.02.029

13. Горальський Л. П. Основи гістологічної техніки і морфоорункціональні методи досліджень у нормі та при патології / Л. П. Горальський, В. Т. Хомич, О. І. Кононський. - Житомир : Полісся, 2011. - 288 с.

14. Науково-практичні рекомендації з утримання лабораторних тварин та роботи з ними / Ю. М. Кожем'якін, О. С. Хромов, М. А. Філоненко, Г. А. Сайфретдінова. - К. : Інтерсервіс, 2017. - 179 с.

perioperative care of the burn-injured patient. Anesthesiology. 2015;122: 448-64. DOI: 10.1097/ALN.0000000000000559.

9. Young AW, Dewey WS, King BT. Rehabilitation of burn injuries. Physical Medicine and Rehabilitation Clinics of North America. 2018;30(1): 111-32. DOI:10.1016/j.pmr.2018.08.004 10. Pyatnytsky OYu, Yakovleva LV, Koshova OY. [Experimental study of pharmacological properties of the cryopreserved swine skin substrate]. Klin Farmatsiia. 2013;17(1): 56-62. Ukrainian.

11. Tsymbalyuk AV, Guda NV, Kyryk OO. [The use of crushed substrate of lyophilized xenograft skin substrate for local treatment of burn patients with infected wounds of IIIIV degrees]. Shpytalna khirurhiia. 2013;1: 81-4. Ukrainian.

12. Yamamoto $\mathrm{T}$, Iwase $\mathrm{H}$, King TW, Hara $\mathrm{H}$, Cooper DK. Skin xenotransplantation: Historical review and clinical potential. Burns. 2018;44: 1738-49. DOI: 10.1016/j. burns.2018.02.029.

13. Goralsky LP, Khomych VT, Kononsky OI. Fundamentals of histological technique and morphofunctional research methods in normal and in pathology. [Основи гістологічної техніки і морфоорункціональні методи досліджень у нормі та при патології] Zhytomyr: Polissia; 2011. Ukrainian.

14. Kozhemyakin YuM, Xromov OS, Filonenko MA, Sajfetdinova GA. Scientific and practical recommendations for keeping laboratory animals and working with them. [Haуково-практичні рекомендації з утримання лабораторних тварин та роботи з ними] Kyiv: Interservis; 2017. Ukrainian. 